JAKUB KORNHAUSER

Uniwersytet Jagielloński w Krakowie

e-mail: jakub.kornhauser@uj.edu.pl

\title{
Gellu Naum's The Advantage Of Vertebrae. A Solitary and Terrible Object
}

\begin{abstract}
The paper presents one of the most interesting experiments in the Gellu Naum's Surrealist repertoire, The Advantage of Vertebrae, a cycle of collage poems, created originally in the 40's, but published late in 1975's book The Description of the Tower. The poem is de-poetized by removing its teritory to the new context of the fashion-plate's illustrations. This strange piece of art could also anticipate the formal experiments of the 50's and 60's, notably the concrete poetry, or be treated as a representative of liberature, the category invented by Polish poet Zenon Fajfer back in the late 90's. Fajfer underlines the material aspect of literature as an object: from this point of view, The Advantage of Vertebrae becomes the laboratory of the poetry itself, gaining a new, unlimited identity.
\end{abstract}

Keywords: avant-garde, liberature, experimental poetry, concrete poetry, collage.

\section{Inside Poetry, Outside Poetry}

In Writing Degree Zero, Roland Barthes examines the dialectical notion of object by putting its status between the poetic language and the material coherence spheres. Says Barthes:

At the very moment when the withdrawal of functions obscures the relations existing in the world, the object in discourse assumes an exalted place: modern poetry is a poetry of the object. In it, Nature becomes a fragmented space, made of objects solitary and terrible, between the links between them are only potential. Nobody chooses for them a privileged meaning, or a particular use, or some service; nobody imposes a hierarchy on them, nobody reduces them to the manifestation of a mental behaviour, or of an intention, of some evidence of tenderness, in short. The bursting upon us of the poetic word then institutes an abolute object. ${ }^{1}$

${ }^{1}$ R. Barthes, Is There Any Poetic Writing? [in:] idem, Writing Degree Zero, trans. A. Lavers, C. Smith, New York 2012, p. 50. 
By this definition Barthes draws his attention to at least three aspects of the poetry-materiality tandem. The first one is a lack of any substantial difference between the sign (as in the piece of text) and the object (as a part of the reality's texture). Thus, "The Realm of the Sign" encapsulates everything that lies beyond the inner textual world. The second one is an autonomy of the word-object, which is anthropomorphised in a way, being "solitary" and "terrible" and having control over men, or even excluding them from their habitat. The third one underlines the hybrid structure of the word-object; it's not only an echo of de Saussure's Structuralist binary oposition of signifiant and signifié but also a definition of the piece of art itself. Its paradoxal status, claims Barthes, provokes the states "[...] full of gaps and full of lights, filled with absences and overnourishing signs, without a foresight of stability of intention." ${ }^{2}$ In consequence, the ideal has to derive from the collage of unequivocal elements, being in the same time a piece of art and a manifestation of its own identity, an autonomous object and a part of the materiality of the book. There is no better example of this perplexity, I dare to say, than The Advantage of Vertebrae by Gellu Naum.

Inside the world of his unrestrained imagination, the Surrealist poet Gellu Naum (1915-2001), one of the prominent Romanian writers, the leader of the Romanian Surrealist Group ${ }^{3}$, in the mid-40's has created a masterpiece beyond the traditional classification. Unskillful eye would come easily to say that the fundamental elements of this mysterious text build a hermetic system of poetry, puzzle signs and meanings, rules and relationships, locations and characters. In this way, any ambiguity would be compromised, and any attempt to enrich the textual reality of the new element would be either injected into the existing framework of interpretation, or deliberately displaced from a closed, motionless system. Unique even in the Gellu Naum's Surrealist repertoire, The Advantage of Vertebrae, in the same time being a cycle of ten collage poems and a hybrid form of the long poem, or the collage piece of art, created originally circa 1945, was eventually published inside the book The Description of the Tower (Descrierea turnului) in 1975. The text is, so to speak, "de-poetized" by removing its space into the new context of the retro-style-fashion-plate's illustrations. The structure of the text is thus decomposed, disjoined, unbridled, oblated to the level of a signature under a photo. Altough it rejects traditional versification, and even punctuation, Naum's work is far from being an uncontrolled, amorphous outpouring of the unconscious; in the middle of this graphic/textual teritory, poetry seeks for its own destination, subsequently functioning, as it was in the Surrealist theories of the 20's and 30's, more as an object than a traditional poem. ${ }^{4}$

The Advantage of Vertebrae cycle consists of ten boards (or, in fact, "segments" or "panels", to be exact), covering ten pages in the paper edition. In the

2 Ibid., p. 48.

3 Founded in Bucarest, the Romanian Surrealist Group was active between 1940 and 1947; its members: Naum, Gherasim Luca, Paul Păun,Virgil Teodorescu and Dolfi Trost published several manifestoes, as well as books of poetry and prose, in Romanian and in French.

${ }^{4}$ André Breton highlights the necessity of the obejct to be claimed "[...] in the broadest philosophical sense." See A. Breton, Surrealist Situation of the Object. Situation of the Surrealist Object [in:] idem, Manifestoes of Surrealism, trans. R. Seaver, H.R. Lane, Ann Arbor 1972, p. 258. 
original form, all of the collage-like works were presented on a single canvas, inside a wooden frame painted pink. The decision whether a board is equivalent to one poem, whether it contains more than one poem, or it can only be regarded as a cycle, although very intriguing one, in this case seems irrelevant. In accordance with the specificity of the poetic act, and probably with the intentions of the author, the distinctive categories of beginning and end, center and periphery, as well as any instructions regarding the reading order lose their meaning. Since we are dealing with a work of poetry as much as graphic, we assume that each component is also a separate entity, which can be viewed in isolation from the larger part. The cycle's genological vagueness is significant. It is hard to accept "a poem" as a suitable term to denote a collage-like form, which overwhelming - let's say, at least visually - aspect certainly lies in its illustrations, while the text is reduced into the role of a signature under a photo, a minor note out in the margins. Nonetheless, these "gaps" and "ligths", stresses Barthes, only evoke the "irruption and vibration" of the poetic word.

Assuming that each of the ten panels "lives its own life", if only because of the location on subsequent pages of the volume, I suggest to look at a specific interdependence that has been attributed to them. Every board contains both visual and verbal elements. The most important characteristics of each boards are therefore: 1) being a collage mixing some "graphic" elements from the old journal (illustrations and drawings, tables, lists, prices, numbers identifying all of the "products") with "verbal" elements, which are essentially a fragmented piece of poetry, a dispersed form of a Surrealist poem ${ }^{6} ; 2$ ) direct replacement of the words being a part of captions, headlines, product names and description, titles, figures, statements, comments, consistent with the visual logic of writing "in colour", i.e. with a varied fonts, using tables, frames; 3) lack of connection between the "verbal" elements (the meaning of words, the content of subsequent fragments) and the "graphic" ones (illustrations depicting the garment); 4) coexistence of all the elements in one space, a radical de-poetizng of the poetry by pressing the individual words between the numbers, frames, images and other "graphic" elements; 5) a constant presence of the specific "graphic" motifs, illustrations and drawings typical for the old-style-fashion-plate's poetics; what is more, each of the panels is devoted to a different element of clothing (from coats, dresses or costumes to hats, shoes and socks).

The main characteristics of the "verbal element" in each of the panels are in turn: 1) incompatibility of the consecutive text fragments - single words, groups of words, sentences; a special kind of treatment to avoid references to hypothetical entire form, obtained by rejecting the traditional continuity of writing, a break with the logic of cause and effect relationship, splitting the internal structures of the text, and a specific looseness of juxtaposition; 2) surrealist-driven technique of automatic writing or the stream of consciousness, though in fact more akin to the French

${ }^{5}$ R. Barthes, op. cit., p. 50.

${ }^{6}$ Actually, The Advantage of Vertebrae once was published also in non-collage version, without the "graphic" elements and coagulating the whole poem into one piece. See G. Naum, Opere I. Poezii, ed. S. Popescu, Iaşi 2011, pp. 407-435. 
Cubist poet Pierre Reverdy's concept of "rational surrationality", newly-established in André Breton's first "Manifesto of Surrealism"; the image itself is a pure product of the senses build with the approximation of the two realities. The more these compounds are distant, the stronger the image, the more evocative power and poetic reality it will have. Instead of pure randomness, the deliberate lack of control over the text - intentional freedom of association ${ }^{8}$; 3) separation of some units, words, groups of words, verses using modified fonts, also with bold and zooming (the headers of pages and their separate parts), italics (single words or groups of words within individual fragments, and some "isolated" and dispersed fragments). The fonts which build these "text islands" correspond probably with the font used in the "original" (if there is any, of course) text of the fashion magazine.

\section{The Advantage of Vertebrae as a Collage}

Certainly, we are dealing with a specific act of poetry, far beyond the traditional area of interest. Ion Bogdan Lefter describes its unusual character:

Strange series. Poems? Yes, poems, but also proper lines, strings of words that can be read by jumping here and there on the surface of the paper. And not only: the individual pages are in fact a part of the old fashion catalog, from the late nineteenth, early twentieth century. Verses, words, groups of words scattered among mannequins, dresses, skirts, gloves, bags, shirts, shoes and hats. ${ }^{9}$

Lefter notes that part of the series includes works which are in fact "collage poems" and illustrations, photographs, or drawings, as if taken out of the old fashion magazines. He also asks the question of their genre characteristics. Are they texts? Images? Picture-lyrics? A special version of Voronca's and Brauner's picture-poetry? ${ }^{10}$ In a similar vein speaks Simona Popescu: "The cycle [...] contains a number of ten collages of text and graphics (reproduction of the old articles of clothing, resembling a catalog with prices and sales code)." ${ }^{11}$ Ion Pop, though, describes the "verbal" and "graphic" elements as separate wholes, focusing on the mutual relations between word, poetry and picture, in this case, illustrations from a fashion magazine:

Those few pages of fragmentary poems, arranged like valves of surprise and wonder of poetry, between the cutouts from a old catalog of fashion, with detailed measures of clothes, seem even more contrasting in relation to the fossil sites presenting dusty mannequins, French, pret-à-porter carrying a suggestion of sameness. ${ }^{12}$

${ }^{7}$ A. Breton, Manifesto of Surrealism [in:] idem, Manifestoes of Surrealism, pp. 20-21.

${ }^{8}$ Ibid., pp. 36-47.

${ }^{9}$ I.B. Lefter, Avantajul lui Gellu Naum. Mic portret cu Avantajul vertebrelor, "Observator Cultural", 1-7.08.2000, no. 23, p. 14 [in my translation - J.K.].

${ }^{10}$ Pictopoetry (Pictopoezie) as a late form of dada-like collage was established in 1924 by Ilarie Voronca and Victor Brauner in "75 H.P.", the sole issue of this Romanian Avant-garde magazine.

${ }^{11}$ S. Popescu, Poezia-reţea [in:] G. Naum, Despre identic şi felurit. Antologie, Iaşi 2004, p. 9 [in my translation - J.K.].

${ }_{12}$ I. Pop, Prefată [in:] G. Naum, Copacul-animal urmat de Avantajul vertebrelor, Cluj 2000, pp. 13-14 [in my translation - J.K.]. 
For Pop, therefore, it's dispersed text that plays a leading role, and constitutes the basis for semantic structure, setting the only point of reference. The relationship between the two distinctive elements is presented by him similarly as the ratio of two separate entires from the dominant position of the text. In the contrary, Simona Popescu treats each piece as a collage "verbal" and "graphic" elements, without giving priority to any of them. Lefter imposes a formula of "pictopoezie", but in order to separate the two phenomena: "[...] rather than a genuine intention to connect the creativity of the verbal with the visual, images used in the The Advantage of Vertebrae are pre-existing, transferred from another reality onto the same page of text, quoted from the unfashionable fashion magazine in the new context." 13 It is interesting how the problem of a preexisting, finished or semi-finished form in a completely new, unexpected context, is created. We refer particularly to techniques typical for early Cubist collages, consisting in pasting into a picture fragments of various materials (newspaper clippings, wallpaper, photography, etc.), developed and transfered into poetry by the Italian Futrists, the Russian Cubofuturists (and later, the Constructivists) and adjusted to perfection at the beginning of Dadaism and Surrealism. Collage, being sistematically enriched with new mutations (like Hausmann's photomontage, Kurt Schwitters' Merz assemblages or fumages created by Wolfgang Paalen), began to be used when creating new poetry, the Avant-garde poets utilised not only newspaper clippings and other worthless objects; they also assumed the Futurist typography borrowed by the Dadaists and translated it into their own world. Breton, for instance, claims the hybridity of the collage-poem the crucial point of the evolution of Surrealist poetry. ${ }^{14}$

It should be strongly emphasized that, similarly to the Futurist collage typography, in his cycle Naum uses the newspaper font, configuring lines of poetic text as signatures under images depicting the garment, or even replacing the etiquettes with lyrics. In consequence we can recognize that we are confronted with either ten pages of the old journal in which the actual signatures of the fashion were replaced by fragmentary text of poetry, without any change in the graphical layout of pages, or with poems broken into many particles, the gap between which being filled with the pieces "cut out" from the erstwhile fashion magazines. It must also be remembered that Schwitters, Ernst and Braque were primarily painters, who put the text elements into the pictorial sphere, while Gellu Naum is a poet who incorporates visual elements into poetry. Max Ernst argued that the collage is based on a strange meeting of two different realities at one plan, obviously referring to the Lautréamont's meeting of sewing machine with an umbrella on the section table, that later became the flagship password of Surrealism. ${ }^{15}$

However, if Schwitters, Ernst or Hausmann arranged their collages in extremely violent way, The Advantage of Vertebrae is built in a more "rational" order, while different elements interact against chaos and randomness. Hence,

${ }^{13}$ I.B. Lefter, Avantajul lui Gellu Naum..., p. 15.

${ }^{14}$ A. Breton, Surrealist Situation of the Object..., pp. 274-277.

${ }_{15}$ Breton calls the concept "possiblity of bringing together two distant realities." Idem, Manifesto of Surrealism, p. 36. 
a rebellious, destructive, nihilistic version of collage gives way to an ascetic one, being a cooperation of words and images rather than a clash between them. The difference is reflected also in the selection and treatment of the material: the Dadaists were not interested in the content of pages torn out of newspapers, nor in their role in the total composition. Collages were produced intentionally relying on the strength of the chance. What is more, they cut out from newspapers mostly fragments of articles, it means: text. Yet in Naum's work the "newspaper reality" are build by pictures instead of the "verbal" elements. These illustrations are removed from original context without affecting their internal autonomy, only moving to the another setting. Of course, "the stability of intenton", says Barthes, cannot be any point of reference until the work's hybridity influences its status.

\section{The Advantage of Vertebrae as a Concrete Poem}

Despite its fundamental position in the $20^{\text {th }}$ century history of literature, the concrete poetry remains underrated or even undisclosed. Being a fine example of a literary terra incognita, the concrete poetry represents a form consisting of both verbal and visual elements and, in consequence, unites the distinctive marks of poetry and painting. With a vague status of a hybrid, as well as the experimental character, this specific genre is situated beyond the traditional categories of analysis and interpretation. Despite the confusion in terminology, though, there is fundamental requirement which the various kinds of concrete poetry meet: concentration upon the physical material from which the poem or text is made. ${ }^{16}$ The most significant component of the concrete poem is language itself, treated predominantly as a graphic structure. Words, reduced to their elements of letters (graphemes) or even maintained as a integral items, can achieve the status of an autonomical being, invoked by Barthes in the "word as an absolute object" statement. Actually, the degree of reduction varies from poet to poet, from poem to poem. Isolated from the system of communication, words gain a new identity, extending from the semantic to the aesthetic pole (this is the crux of their immanent "terrible" status). The visual shape enacts or corresponds in some way to sense of the graphemes or words presented. What is important, the non-linguistic signs or objects function in a manner related to the semantic character of words. In addition to his preoccupation with the reduction of the language, a concrete poet is concerned with establishing his linguistic materials in a new relationship with space (the page or its equivalent) and/or with time (abandoning the old linear measure). Put another way, this means a concrete poem is made as an object perceived rather than read, being a form halfway between the text (poem) and image (picture). Certainly, this is the case of Naum's The Advantage of Vertebrae.

Referring to the Poststructuralist definition of metatextuality (for instance in the Jonathan Culler's classic theories), the concrete poem - as a verbal/visual structure - has to be "uninterpretable", because belongs to its own, interior reality

${ }^{16}$ Emmett Williams stresses the "intermedium" status of concrete poetry which lies between poetry and painting. An Athology of Concrete Poetry, ed. E. Williams, New York 2013, p. vi. 
of signs. In other words, the concrete text is relieved of its servitude to disciplines and contexts outside itself. Therefore, this kind of experimental poetry can be thought as a perfomative art (notably, one of the movement's major figures, Bob Cobbing, published the Performance of Poetry anthology). It can be seen like a painting or composed to be listened to like music. Concurrently, it has to be a specific concept made from possibilities and limitations of specific linguistic materials isolated in a certain space. While consulting the problem, some critics apply the "self-potentiality" term to reveal the multilateral character of a concrete poem.

Of course, the trend for creating collages using pieces of text, subtitles, single words as slogans, was developed in the history of art, such as in pop-art (Tom Wesselmann or Roy Lichtenstein) and the conceptual art in broader meaning, but with the text always in the subordinate role. Therefore, in these considerations the poetry itself seems to be more important than the visual arts, as it uses many different aspects of words and reaches for a variety of ideas from the realm of visuality. Also in this domain Naum's conceptual work proves to be unique. As Ion Bogdan Lefter notes, "Gellu Naum is proposing more surrealist experiments, stretching of the conditions of twentieth-century non-conformism definitive conclusions." ${ }^{.17}$ The Advantage of Vertebrae can be ranked as an experimental piece of art, even comparing to such unconventional proposals as concrete or visual poetry, which have particularly important aspects in graphics and printed text (or the phonetic aspect), while the semantic aspect is consequently limited. Language is degraded, single letters are trying to hide in the most inaccessible corners of the pages, creating strange shapes and patterns. Nevertheless, the visual or concrete poems have much in common with Naum's work, as visuality is generated by the diversity of fonts, or "painted" letters.

Some other examples of poetry using photos, illustrations or drawings, with the "verbal" elements only as a laconic description or commentary, include, for instance, Marcin Sendecki's Szkoci dót $t^{18}$, where infantile drawings, transferred directly from the children's workbook are accompanied by unexpected, absurd comments. A very interesting case could be the Andrzej Sosnowski's volume Nouvelles impressions d'Amérique ${ }^{19}$, containing 59 texts: poems, short prose, various notes or translations, which could be decoded as kind of commentary to dozens of illustrations, scattered among the whole text. As in Naum's cycle, the illustrations and titles of individual works are removed from a different context, namely from one of the poems of Raymond Roussel. The key difference is the fact that the Sosnowski's texts relate directly to the titles and illustrations, seem to be their complements rather than accidental juxtaposition; though they undoubtedly contribute to create the kind of universe of icons, in which text appears next to the graphic element. This tradition has its strong examples in the American Postmodernism, especially in the prose-collages of M. Kasper, the author of All Cotton Briefs. Expanded Edition..$^{20}$ Kasper's works are graphically configured to newspaper notes,

${ }^{17}$ I.B. Lefter, A Separation from Neo-modernism [in:] M. Spiridon, I.B. Lefter, G. Crăciun, Experiment in Post-war Romanian Literature, Pitești 1999, p. 40.

${ }_{18}^{18}$ M. Sendecki, Szkoci dót, Kraków 2002.

19 A. Sosnowski, Nouvelles impressions d'Amérique, Warszawa 1994.

${ }^{20}$ M. Kasper, All Cotton Briefs. Expanded Edition, New York 1992. 
which instantly takes us back to Naum's The Advantage of Vertebrae, making the images (which are collages themselves, such as an eagle with the head of a T.Rex, holding in its mouth a ribbon, paired with the flag of the United States) and the fragment of a text, in form of the press release, letter, an epitaph, or even a food product label, coexist in a single plan. The text itself, however, is not a Surrealist poem, and, like in Sosnowski's work, interacts with the subject of illustration; nonethelss, the paradoxical effect, postulated by Barthes, is maintained.

\section{The Advantage of Vertebrae as Liberature}

As indicated before, The Advantage of Vertebrae is functioning more as an object then a traditional piece of poetry. This peculiar work of art, on one hand, a representative of Romania's Surrealist boom of the 40's, on the second hand could anticipate the formal experiments of the 50's and 60's, notably the concrete poetry. But in the same time, it can be treated as an example of liberature, a term proposed by Polish poet Zenon Fajfer back in the late 90's. Fajfer stresses the material aspect of literature as an object. From such a point of view, The Advantage of Vertebrae becomes the laboratory of the poetry itself, gaining a new, unlimited identity. In consequence, it can no longer be interpretable, analysis being a sole form of investigation. Fajfer, in his manifesto "Liberature (appendix to a dictionary of literary terms)", states that

if the writer's medium is language, then this must also include writing, and along with it, its visual-spatial features may also be significant for him. In conclusion he proposed to gather into one literary genre those works in which writers devise the whole book, including its typography, and call it liberature after Latin liber, both "free" and "a book". ${ }^{21}$

Fajfer, convinced that language is not the only medium of literature, turns his attention onto visual aspect of the literary work. The space of the page itself can also be treated as a instrument of artistic expression: "Who said that the colour of the page must always be white? Does the definition of FORM [...] also include the physical shape of letters and sentences?"22

In consequence, literary text is replaced by "the book", understood as an aesthetic object in a specific material shape, including cover, kind of paper, format, the number of pages, the direction of writing, colour and type of the font, and the physical shape of words and letters. Naum's cycle, with its visual-verbal character and original internal structure, could be a fine example of liberature (or pre-liberature), in a generic sense. The term's achronic status allows us to classify the work from 40 's as an ordinary representative of the genre without necessity of calling it a "primordial" form. The ideal of liberature, the complete integrity of the volume ("the hyperbook"), in Naum's case appears to be simultaneously preserved (the shape of the cycle inside the whole book) and questioned (the fragmentary nature of its

${ }^{21}$ Z. Fajfer, Liberature. Appendix to a Dictionary of Literary Terms [in:] idem, Liberature. Total Literature, trans. K. Bazarnik, Kraków 2010, p. 154.

22 Ibid. 
parts). The crucial element is to consider The Advantage of Vertebrae as a trangeneric artifact, which fulfilles the fundamental conditions of liberature, enumerated by Katarzyna Bazarnik: non-verbal and typographic means of expression, spatial structure of the text, iconicity, self-reflexivity or metatextuality, hybridity or polymediality, interactivity or ergodic quality, and materiality. ${ }^{23}$ As a result, the "journal-structure" loses its serial nature, and becomes a part of a specific object. But is this belief in the uniqueness of the cycle grounded in reality? Some literary critics, like Simona Popescu among others, consider the original presentation of The Advantage of Vertebrae an art installation, while it was published as a kind of picture in pink wooden frames, and its individuality should not be questionable. On the other hand, regarding the newspaper lines as poetic signatures, albeit considerably developed (but with the aim of "appropriation" of a fashion magazine), we see a direct relationship between the collage-poem of Naum and Marcel Duchamp's ready-mades, notably Bottle Dryer, or Bicycle Wheel. Besides, Surrealist themselves intercepted Duchamp's concept and claimed ready-made a "manufactured objects promoted to the dignity of art objects by the choice of the artist" ${ }^{24}$; hereby, they became the Surrealist ones.

Another problem is the fact that the prevalence of the cycle is not widely available in its original form, but reprinted in the books, reproduced in thousands of copies in various anthologies and selections. Therefore, all published versions gain the status of the original, what resembles on the one hand, the "ready-mades" identity, while on the other hand is far from logic of Duchamp's provocation; it was, after all, the French creator who draw his attention on the individualization of the mass product, while in our case we could talk more about dissemination of original, unique work of art, what is indisputably one of the cardinal laws of liberature. The work's "natural", so to speak, ability to self-reproduce diminishes its uniqueness, but not its autonomy. In consequence, the Naum's hybridic cycle can be called an example of "total literature", or liberature, the "hyperbook" in its fundamental form, ${ }^{25}$ in a sense of an oeuvre under the all-embracing control of itself. ${ }^{26}$ Moreover, it underlines it "objectual" status, varying from sign-centered to material-centered forms.

\section{Beyond classification}

Noting the fragmentary nature of The Advantage of Vertebrae series, we can recall the fundamental remarks made by Peter Bürger on the experimental piece of art: for the Avant-garde poet, material is nothing more than just the material itself: an avant-gardist action is to kill the "living" material, for instance,

${ }^{23}$ K. Bazarnik, Liberature or on the Origin of Literary Species [in:] Z. Fajfer, Liberature. Total Literature, trans. K. Bazarnik, Kraków 2010, p. 161.

24 A. Breton, Surrealist Situation of the Object..., pp. 276-277.

25 Z. Fajfer, Liberature or Total Literature [in:] idem, Liberature. Total Literature, pp. 233-237.

${ }^{26}$ I develop this idea in the article Narodziny hiperksięgi. Fajfer, Radovanović, Naum, "Studia Litteraria Universitatis Iagellonicae Cracoviensis" 2016, no. 11, pp. 187-200. 
on snatching it from suitable functional context. Where a "classic" recognizes and respects the importance of carrier material, an "avant-gardist" sees only an empty sign, which only he is himself able to give a proper meaning. He pulls its material from the entireness of life, isolating it and disintegrating into small pieces, guided by the intention to give them meaning (in fact, meaning can also serve as an indication that any sense no longer exists). It is impossible to create a work that would constitute an organic whole, without assembling the material with fragments. ${ }^{27}$ Ion Pop, calling the Naum's poems fragmented, in fact separates visual elements from the text ones. We are dealing here with a rather special variety of dispersion. The more appropriate term for its specificity could be "piece", maybe "passage" or "network", where you can move in all possible directions. Simona Popescu observes: "The Advantage of Vertebrae can be read from top to bottom, from right to left, from inside to outside, at random; the images and texts seem to follow the logic of reader's choice." ${ }^{28}$

Gellu Naum's poetic act could be characterized by its openness or indefiniteness. It defies the necessity of interpretation, got a certain mobile, kaleidoscopic ability to re-emerge in the eyes of the reader as something peculiar, offering a new objectual perspective. The text itself, and the whole collage-like form standing behind it, thus represents a self-sufficient and autonomous product that differs significantly from the common ideas on poetry. A certain ambivalence of its status lies in the fact that on one hand it is characterised by the author's evocation of poetic imagination, a number of subjective images, closely related to their creator, a labyrinth of memory and imagination, while the on the other - it can be the work of any readings, open wide, manifesting its ambiguity, vagueness, polyphony, inviting to cooperation, living its own life, constantly renewing its importance, offering endless possibilities while reading, self-multiplying its own perspective, and finally aspiring to become a surrogate for the world. The author's inner world in which the reader is always on the outside?

However, while the prevalence of The Advantage of Vertebrae seems to be a surrogate for the real world, it also separates world of poetic reality. Hence, the strength of the cycle lies also, as invoked by Ion Bogdan Lefter, in its unpretentiousness, which is the effect of authenticity. And in consquence allowing the belief that the technique used by the author is not just a joke, not an empty game, leading the reader astray, but rather a kind of labyrinth-like poetic confession, an uneasy exploration of inner space (in the Henri Michaux's term of l'espace du dedans ${ }^{29}$ ). "Decades pass, age is gone, and the poet still writes about what is alive and lives as he writes. He writes about the other side, which leads to prescribe a long story about life, just accidentally broken into rows and books. ${ }^{"}{ }^{30}$ Is it possible that behind the mask of the Surrealist, proposing an experiment without the proper necessity of exegesis, peeped out a spiritual metaphysician?

${ }^{27}$ See P. Bürger, Theorie der Avantgarde, Frankfurt am Main 1974.

${ }^{28}$ S. Popescu, Poezia-reţea [in:] G. Naum, Despre identic şi felurit. Antologie, Iaşi 2004, p. 10.

${ }^{29}$ Michaux used the term to describe "ideas beyond the visible world." See H. Michaux, L'Espace du dedans, Paris 1944.

${ }^{30}$ I.B. Lefter, Avantajul lui Gellu Naum..., p. 14. 
The experimental poets, like Naum himself, debate frequently on the question of semantics. Some of them, for instance Miroljub Todorović in the Signalist theories or Jiří Kolár in his "de-static poetry", are insisting upon the necessity for poetry to remain within the communication area of semantics, others are convinced that poetry is capable of transmitting other kinds of information - especially purely aesthetic one (the case of visual or concrete poetry). But no matter where a poet stands with respect to semantics, he undoubtely holds the conviction that the "old-fashioned" grammatical/syntactical structures are no longer adequate. In other words, an experimental poet seeks to relieve the poetry of its anachronic ideas, symbolic reference, traditional contexts and emotional content. It is necessary to bear in mind that after the lesson of the avant-garde (specifically from Futurism to Surrealism), the revolutionary attitude towards the centuries-old conventions must not be underestimated. Considered as a signum temporis, experimental poetry anticipated in some way the postmodernity in its wider meaning, bringing the "decline of the arts" conviction for the first time after World War II. On the other hand, its status appears to be miscellaneous as seen from different perspectives, as it initiated an interdisciplinary genre by searching for new artistic horizons.

This, of course, puts a special kind of responsibility on the reader. In this very situation, he is obliged to perceive the poem as an object and, what is even more significant, participate in the act of creating it, while the poem (regardless whether we call it a collage poem, a concrete poem, a liberatic work, or even simply a Surrealist object-poem) communicates first and foremost its internal structure. To be more precise, there can be no figure of the reader when refering to The Advantage of Vertebrae, but only the co-author one, who constructs his own version of a poem instead of interpreting it. The work itself looks like being programmed to stimulate the permanent process of rebuliding its structure. Eventually, let's return to Barthes; when he states that the poetic objects have a special kind of inner autonomy and, I shall repeat, "nobody chooses for them a privileged meaning, or a particular use, or some service; nobody imposes a hierarchy on them, nobody reduces them to the manifestation of a mental behaviour, or of an intention, of some evidence of tenderness", it means that any piece of art with the hybridic nature could encapsulate an objectual identity (objectual, or non-human, in a way). Naum's work has to be a good example of it: its elements, both "verbal" and "graphic", "reproduce the depth and the singularity of an individual experience" due to their "abruptness". ${ }^{31}$ Abruptness, let's say, being a part of its double existence, a material installation, and a "paper", textual representation, which leads it to be "solitary" (highly original and autonomous) and "terrible" (uncanny and peculiar) at the same time.

${ }^{31}$ R. Barthes, op. cit., p. 45. 


\section{Bibliography}

An Athology of Concrete Poetry, ed. E. Williams, New York 2013.

Barthes R., Is There Any Poetic Writing? [in:] idem, Writing Degree Zero, trans.

A. Lavers, C. Smith, New York 2012.

Bazarnik K., Liberature or on the Origin of Literary Species [in:] Z. Fajfer, Liberature. Total Literature, trans. K. Bazarnik, Kraków 2010.

Breton A., Manifesto of Surrealism [in:] idem, Manifestoes of Surrealism, trans. R. Seaver, H.R. Lane, Ann Arbor 1972.

Breton A., Surrealist Situation of the Object. Situation of the Surrealist Object [in:] idem, Manifestoes of Surrealism, trans. R. Seaver, H.R. Lane, Ann Arbor 1972. Bürger P., Theorie der Avantgarde, Frankfurt am Main 1974.

Culler J., Literary Theory, Oxford 2000.

Fajfer Z., Liberature. Appendix to a Dictionary of Literary Terms [in:] idem, Liberature. Total Literature, trans. K. Bazarnik, Kraków 2010.

Fajfer Z., Liberature or Total Literature [in:] idem, Liberature. Total Literature, trans. K. Bazarnik, Kraków 2010.

Kasper M., All Cotton Briefs. Expanded Edition, New York 1992.

Lefter I.B., A Separation from Neo-modernism [in:] M. Spiridon, I.B. Lefter, G. Crăciun, Experiment in Post-war Romanian Literature, Piteşti 1999.

Lefter I.B., Avantajul lui Gellu Naum. Mic portret cu Avantajul vertebrelor, "Observator Cultural", 1-7.08.2000, no. 23.

Michaux H., L'Espace du dedans, Paris 1944.

Naum G., Descrierea turnului, Bucureşti 1975.

Naum G., Opere I. Poezii, ed. S. Popescu, Iaşi 2011.

Pop I., Avangarda în literatura română, Bucureşti 1990.

Pop I., Prefaţă [in:] G. Naum, Copacul-animal urmat de Avantajul vertebrelor, Cluj 2000.

Popescu S., Poezia-reţea [in:] G. Naum, Despre identic şi felurit. Antologie, Iaşi 2004. Sendecki M., Szkoci dót, Kraków 2002.

Sosnowski A., Nouvelles impressions d'Amérique, Warszawa 1992. 